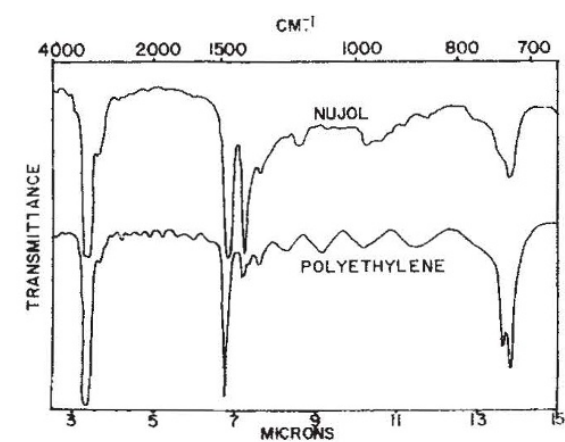

Fig. 1. Infra-red absorption spectra of 'Nujol' in a capillary film on sodium chloride windows and of polyethylene film in two layers each of $0.002 \mathrm{in}$. thick

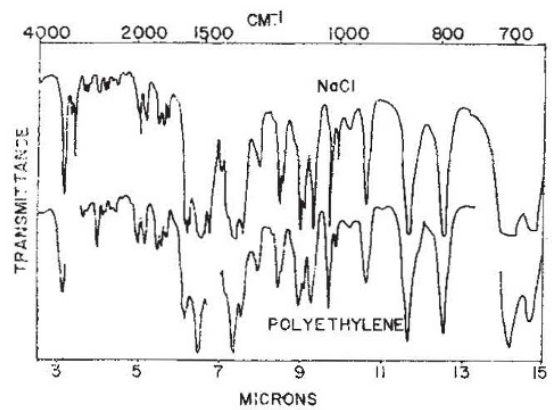

Fig. 2. Infra-red absorption spectrum of nitrobenzene as a capillary film either between sodium chloride windows or between two layers of $0.002 \mathrm{in}$. polyethylene film. In the latter case a simlar thickness of polyethylene was in the reference beam. Break in the bottom curve indicate regions which are not usable because of polyethylene absorption

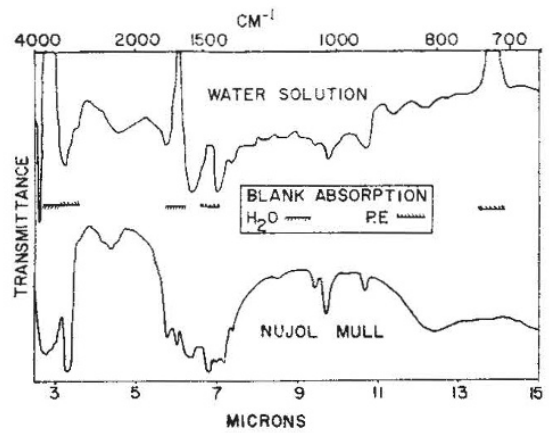

Fig. 3. Infra-red absorption spectrum of sodium acetate trihydrate as a 'Nujol' mull between sodium chloride windows or in saturated aqueous solution as a capillary film between polyethylene sheets. In the latter case the reference beam passed through a capillary film of water in polyethylene. Hatched lines indicate regions where high absorption by water or polyethylene makes sample spectrum indistinguishable

spectrum there is little of interest, but the two techniques appear to give similar bands. Both poly. ethylene and 'Nujol' show strong absorption at 13.5-14.0 $\mu$. The difference appears because for polyethylene this was compensated by a reference sample.

The major objection to the polyethylene technique arises from the difficulty of controlling sample thickness. The flexibility of thin polyethylene prevents spacers being used with any accuracy. However, for qualitative applications with aqueous solutions polyethylene seems in many ways preferable to the other cell materials which are available.

Thanks are expressed to the Kordite Corporation, Macedon, New York, for supplying the polyethylene sheet used in these experiments.

Trevor Rominson

Biological and Food Research Center, and

Department of Bacteriology and Botany,

Syracuse University, Syracuse 10, N.Y. May 11.

${ }^{1}$ Gore, R. C., Barnes, R. B., and Petersen, E., Anal. Chem., 21, 382 (1949).

${ }^{2}$ Blout, E. R., and Lenormant, H., J. Opt. Soc. Amer., 43, 1093 (1953). 3 Potts, W. J., and Wright, N., Anal. Chem., 28, 1255 (1956).

Ellenbogen, E., Meeting Ábstracts, American Chenical Soeiety, September $1959,24 C$.

\section{Stability of Metal Complexes of Oxine and its Sulphonic Acid}

The stabiLity constants for the complexes of 8-hydroxyquinoline-5-sulphonic acid (oxine sulphonic acid) have recently been compared with those for 8-hydroxyquinoline (oxine). For any given metal, the reported difference between corresponding constants was large (up to 10,000-fold) and a plausible explanation was offered 1 . However, the comparison is not valid because the values for the sulphonic acid were determined in water and those of the 8-hydroxyquinoline in 70 per cent dioxan².

When a comparison is made between results obtained in the same solvent, it is seen that the presence of the sulphonic acid group has only a small effect on the stability constants. This is clearly shown by the typical values (Table 1), all of which were obtained in water at $20-25^{\circ}$.

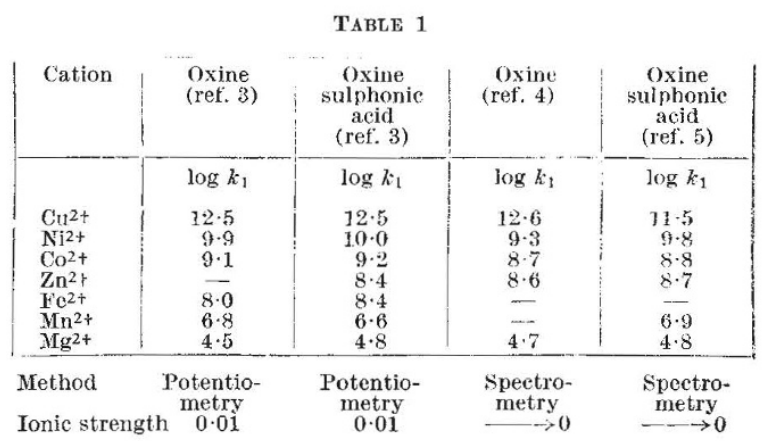

Department of Medical Chemistry,

Adrien Albert Australian National University, Camberra

Department of Chemistry

Reino Nasanen

University of Helsinki, Helsinki

Aug. 11.

${ }^{1}$ C. F. Richard, R. L. Gustafson and A. E. Martell, J. Amer. Chem. Soc., 81, $1033(1959)$

L. E. Maley and D. P. Mellor, Austral. J. Sci. Res., 2, A, 92 (1949).

A. Albert, Biochem. J., 54, 646 (1953).

5 R. Näsänen and E. Uusitalo, Acta Chem. Scand., 8, 112 (1954). 